\title{
How TIF Districts Can Help Battle FOOD INSECURITY IN INDIANA
}

\author{
CARLA UHLARIK ${ }^{*}$
}

\section{INTRODUCTION}

Jane Smith is a single mother with three young daughters. As she does every weekday night, she settles all three children in for bed. She turns off the television and all the lights in the three-bedroom apartment except the one over the kitchen table. She hasn't eaten since breakfast and ignores her stomach as she slumps into a chair. She pulls out her planner, reheats a cup of coffee, and shuffles through the day's mail — a gas bill, an electric bill, a credit card statement, and a past due invoice from her eldest daughter's recent orthodontist appointment. She lists out this month's expenses and calculates. Luckily, she sold the car last month so she no longer needs to pay the monthly car insurance premium or loan payment. She sighs to herself as she realizes this will be another tight month. She will only have around one hundred dollars to spare after everything is paid to make it the last two weeks of the month before her next paycheck. Slowly, Jane's anxiety creeps in. How will she make the one hundred dollars spread over two weeks? Jane's mother also recently had to move in with Jane, as she couldn't take care of herself. And the slew of doctor appointments for her mother-as well as taking care of her three daughters - only allows Jane to work part-time at the local bank as a teller. Perhaps the last thing on Jane's mind is a ensuring her family has wellrounded wholesome meals.

Likewise, government assistance falls short of allowing Jane to afford anything close to a well-rounded, healthy meal. Her local grocers charge much higher rates for spinach, broccoli, milk, and eggs than for pasta and frozen foods. There is a more affordable food store miles away, but the trip will require a longer commute and carefully planned day. Bus money is already taking away twenty dollars each week.

Jane decides that the remaining sixty dollars will go towards food for the family; any emergencies will be put on the credit card. Fortunately, the school will provide a few meals for her daughters through the National School Breakfast Program and National School Lunch Program. Her two oldest daughters are struggling in school, and their grades are slipping, which they justify with constant excuses that they cannot concentrate. Meals these past few months usually rotate between a hamburger casserole, chicken nuggets, chips, cheese sandwiches, pasta, and waffles. She starts googling, "meals for under \$20" and "healthy cheap meals." Unfortunately, there are not many options, let alone options she thinks her daughters will enjoy. She resolves to pasta for a few nights

* J.D. Candidate, 2019, Indiana University Robert H. McKinney School of Law; B.A. 2013, University of Michigan - Ann Arbor, Michigan. I would like to thank my faculty advisor, Professor Cynthia Baker, for her constant support and insight during the Note development process. I would also like to thank my husband for his relentless love and support during this Note development process. 
this week, oatmeal for a couple more nights, and a casserole dish. This will allow her to buy a few healthy snack foods for after school. She takes a deep exhale. They'll scrape by yet another two weeks.

Though the fictional story above seems like a myriad of worse-case scenarios, it is a reality for many; hundreds of thousands of families in the United States face food insecurity for all of the reasons listed above. ${ }^{1}$ And despite being made up of acres upon acres of farmland, families in Indiana are no exception. ${ }^{2}$ In fact, Indiana has outpaced many other states in food insecurity, and nearly one in seven Hoosiers do not have stable, reoccurring meals. ${ }^{3}$ Data reveals even more dire statistics for children in Indiana, with nearly one in five facing hunger. ${ }^{4}$ In 2016, 65\% of students in Indianapolis Public Schools qualified for free breakfast and lunch programs. ${ }^{5}$

Comparison of the United States Department of Agriculture's ("USDA") data from the 2010 Food Access Research Atlas Map ("Food Atlas") to the 2015 Food Atlas showed that although many states were reversing the food insecurity trend, Indiana's food insecurity actually worsened. ${ }^{6}$ The most prevalent deserts in Indiana are in the metropolitan areas like Indianapolis, Gary, and Fort Wayne. The maps show low-income, low-access tracts in dark gray. ${ }^{8}$

1. See generally Real Stories of Hunger, FEEDING AMERICA, http://www.feedingamerica. org/hunger-in-america/real-stories-of-hunger/?referrer $=$ [https://perma.cc/XSF3-X5UF] (last visited July 7, 2019).

2. See Food Insecurity in Indiana, FEEDING AMERICA, http://map.feedingamerica.org/ county/2 015/overall/indiana [https://perma.cc/5NGQ-DFYN] (last visited July 7, 2019).

3. Veronica Carter, One in Seven Hoosiers is Hungry, Pub. News Serv. (May 4, 2017), http://www.publicnewsservice.org/2017-05-04/hunger-food-nutrition/report-one-in-seven-hoosiersis-hungry/a57553-1 [https://perma.cc/2PFP-SPRS].

4. Id.

5. Tami Silverman, Help Fight Child Hunger this Summer, IndYSTAR (June 3, 2016, 9:53 AM), https://www.indystar.com/story/opinion/2016/06/03/hungry-summer-manychildren $/ 85338298 /$ ?from=global\&sessionKey=\&autologin $=[$ https://perma.cc/V58G-W32K].

6. See Jill Sheridan, Food Insecurity Rises in Indiana Drops Nationally, WFYI INDIANAPOLIS (Sept. 12, 2016), https://www.wfyi.org/news/articles/food-insecurity-rises-inindiana-drops-nationally [https://perma.cc/MQ9V-WFYB]. See generally Food Access Research Atlas, U.S. Dep't Agric., Econ. Res. Serv. (Dec. 5, 2017), https://www.ers.usda.gov/dataproducts/food-access-research-atlas/documentation/ [https://perma.cc/E5HW-H3LE].

7. See generally Food Access Research Atlas, supra note 6.

8. $I d$. 


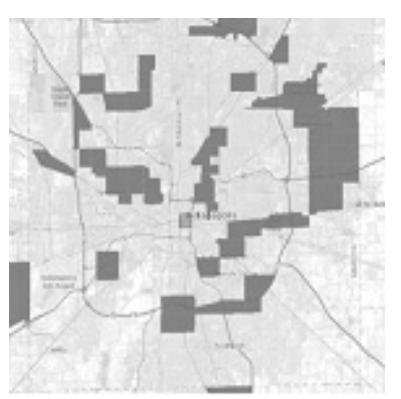

Indianapolis

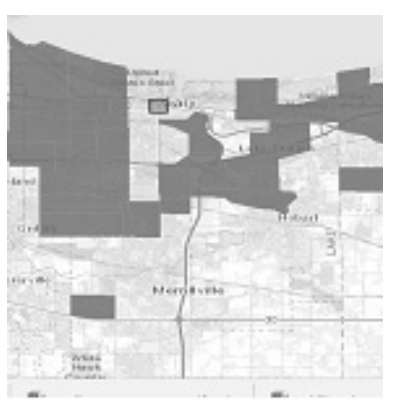

Gary

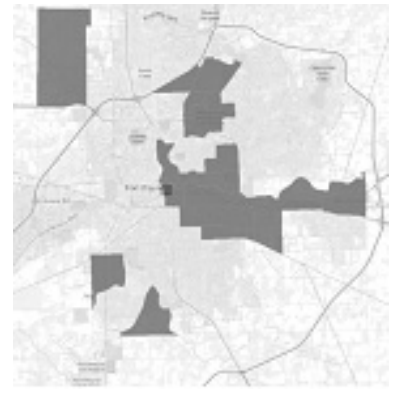

Fort Wayne

The Indiana General Assembly has introduced legislation time and again to try and solve the food insecurity issues in Indiana, but has ultimately failed to make any substantial changes. As a result, many communities have taken it into their own hands to solve the food insecurity problems in the forms of local community gardens and pantries, but these are just quick fixes. ${ }^{9}$

Along with the increase in hunger in Indiana, there has been an unrelated increase in tax increment financing districts. Although the two areas seem independent of one another, tax increment financing ("TIF") districts - an economic development tool used by forty-nine states in the U.S. - may offer a solution to reducing food insecurity in metropolitan areas. ${ }^{10}$ Many of Indiana's TIF districts overlap or border with the food deserts designated by the USDA. ${ }^{11}$ For instance, in Indianapolis, parts of the North Midtown TIF district, HoTif district, and Avondale Meadows TIF district overlap with food deserts.

This Note explores the possibility that TIF could be a tool to battle food insecurity. Part I of this Note discusses the basics of food deserts and food insecurities, and how Indiana, in particular, is affected. Part II of this note then gives a brief overview of the portion of the Indiana Code that regulates TIF districts how TIF has been used in Indianapolis, and the debate that surrounds TIF in Indiana. Part III proposes a solution to Indiana food insecurity by adding provisions in the Indiana Code that would allow redevelopment commissions to fast-track TIF districts in areas labeled as food deserts. This Note concludes that

9. E.g., Leigh Denoon, A Growing Movement Tries to Tackle an East Side Desert, WYFI: HEALTH (June 6, 2017), https://www.wfyi.org/news/articles/in-indianapolis-a-growing-movementtries-to-tackle-an-east-side-food-desert [https://perma.cc/GWT6-XX2T]; Maureen C. Gilmer, Farm on Wheels will Deliver Fresh Produce to Indy Food Deserts, InDiAnAPOLIS STAR (June 30, 2017, 7:00 AM), https://www.indystar.com/story/life/2017/06/30 /indy-food-deserts-get-specialdeliveries-farm-wheels/424144001/ [https://perma.cc/FVV9-X5ML].

10. See Statewide TIF District Summary for Calendar Year 2017, InDIANA GATEWAY FOR PUBLIC UNITS, http://gateway.ifionline.org/TIFviewer/ [https://perma.cc/SM39-5DKL] (last visited July 7, 2019); Food Access Research Atlas, supra note 6.

11. Compare Statewide TIF District Summary for Calendar Year 2017, supra note 10, with Food Access Research Atlas, supra note 6. 
this proposed provision, coupled with Indiana's existing statutory scheme, could be used as a polycentric solution to alleviate food insecurity and food deserts in Indiana.

\section{UNDERSTANDING FOOD INSECURITY}

\section{A. Overview}

An overwhelming amount of data that tracks food insecurity exists. ${ }^{12}$ Studies have been conducted by non-profit organizations, federal authorities, and local and state authorities to analyze food access and availability based on median income and transportation means in a given area. ${ }^{13}$ For instance, Feeding America - the U.S. Hunger Relief Organization mentioned above- has published a Map the Meal Gap since 2011 in collaboration with other non-profit organizations. ${ }^{14}$ The Map the Meal Gap locates food insecurity in every county in the United States. ${ }^{15}$ It uses the USDA's measure of food insecurity, which is "the limited or uncertain availability of nutritionally adequate and safe foods or limited or uncertain ability to acquire acceptable foods in socially acceptable ways." 16 This definition includes tracking a household's need to substitute other basic needs - such as paying for utilities or rent-for food. According to the 2017 Map the Meal Gap, Feeding America found a 13.4\% rate of food insecurity in the United States.

Additionally, the USDA's Economic Research Services uses a similar webbased mapping tool that identifies tracts of land that have both a low-income population and a population with low access to a supermarket. ${ }^{17}$ If a tract has both a low-income population and low access, then it is labeled a "food desert." This map, labeled the Food Access Research Atlas ("Food Atlas"), and the data

12. See generally Feeding America, Mind The MeAl Gap 7 (2017), http://www. feedingamerica.org/research/map-the-meal-gap/2015/2015-mapthemealgap-one-pager.pdf [https://perma.cc/GTC7-BRAU].

13. See generally id.

14. Id.

15. Id.

16. Measurement, U.S. DeP'T AgriC., Econ. Res. SeRV. (Aug. 20, 2018), https://www. ers.usda.gov/topics/food-nutrition-assistance/food-security-in-the-us/measurement/ [https://perma.cc/WJA6-E66Q]. See generally Food Security in the U.S.: Overview, U.S. DEP'T Agric., ECON. RES. SERV. (Sept. 5, 2018), https://www.ers.usda.gov/topics/food-nutritionassistance/food-security-in-the-us/ [https://perma.cc/2VL5-NM3V].

17. See U.S. Dep't of Agric., Econ. Res. SerV., Access to Affordable And Nutritious Food: Measuring And Understanding Food Deserts And Their Consequences 1 (2009), https://www.ers.usda.gov/webdocs/publications/ 42711/12716_ap036_1_.pdf [https://perma.cc/LW2S-RW4L] ("The language in the 2008 Farm Bill defined a food desert as an 'area in the United States with limited access to affordable and nutritious food, particularly such an area composed of predominantly lower income neighborhoods and communities' (Title VI, Sec. 7527).’). 
correlating with it found that over $6 \%$ of the U.S. population live in areas that are both low-income and with low access to the nearest supermarket. ${ }^{18}$

The USDA determines the low-income census-tracts in the Food Atlas using the Department of Treasury's New Markets Tax Credit definition:

(1) The tract's poverty rate is 20 percent or greater; or (2) the tract's median family income is less than or equal to 80 percent of the Statewide median family income; or the tract is in a metropolitan area and has median income less than or equal to 80 percent of the metropolitan area's median family income. ${ }^{19}$

The USDA determines low access by distinguishing both urban and rural areas and the distance a grocery store, supermarket or supercenter is located to that particular tract. ${ }^{20}$ The Food Atlas allows a user to "layer" the map for various access increments. A layer for urban areas can be sorted by 0.5 miles or 1.0 mile from a grocery store, and for rural areas layers can be chosen for either 10 miles or 20 miles. ${ }^{21}$

The study also takes into consideration vehicle access, or whether an individual lives more than 20 miles from the grocery store. ${ }^{22}$ For vehicular access measurement, if a low-income tract and at least 100 households are more than 0.5 miles from the supermarket, then it is considered low access. Also, if an area with a population of at most 500 people, or $33 \%$ of the population, live more than 20 miles away from a grocery store, regardless of vehicle access, this also constitutes low access. ${ }^{23}$

For purposes of this Note, both the Map the Meal Gap and the Food Atlas will be used as examples of areas in Indiana that suffer from food insecurity and areas that are dire enough to be considered food deserts. Again, these two maps show the serious need for certain areas of Indiana to create solutions to its residents' food insecurity issues. Many of the hardest hit areas, as seen in these maps, are in cities in Indiana that already have redevelopment commissions and the infrastructure in place to capitalize on TIF.

\section{B. Epidemiology of Food Deserts and Food Insecurity}

The disappearance of grocery stores in inner cities started in the 1960s with the "white flight" migration of middle and higher income white families moving away from the inner cities and into the suburbs. ${ }^{24}$ This left many of the inner

18. Food Access Research Atlas, supra note 6.

19. Id.

20. Id.

21. $I d$.

22. Id.

23. $I d$.

24. Judith Bell et al., Access to Healthy Food and Why it Matters: A Review of 
cities with small convenience stores, corner gas stations, or "fringe options" for affordable and nutritious food..$^{25}$ In 2008, Congress passed the Farm Bill directing the USDA to conduct a study on food deserts and make recommendations. ${ }^{26}$ At the same time, individual states independently tried to address this issue by offering tax credits to grocers to move to low income areas. ${ }^{27}$ The federal government later tried to mimic these state incentives through the Healthy Food Financing Initiative. ${ }^{28}$ But despite the efforts to bring affordable, healthy nutrition to low-income areas, the problem persists.

Food deserts are a continuing problem in Indiana, as noted in the Introduction of this Note, but food insecurity is also an incessant problem and effects the same low-income population. ${ }^{29}$ Food insecurity is a measure of a household's access to adequate food. ${ }^{30}$ This can range from sacrificing quality in order to have enough food or disrupted eating patterns. ${ }^{31}$ The Map the Meal Gap found that roughly 950,000 Hoosiers (14.4\%) face food insecurity. ${ }^{32}$ This disproportionally affects children; the study found that nearly $20 \%$ of children in Indiana face food insecurity. ${ }^{33}$ Coupled with this finding is the data from the USDA that details nearly 800,000 Hoosiers currently live in food deserts. ${ }^{34}$ Many of the counties that have food deserts are those that have large urban populations such as Marion

THE RESEARCH 6 (2013), http://healthyfoodaccess.org/sites/default/files/GROCERYGAP FINAL_NOV2013_0.pdf [https://perma.cc/7JGM-ERNH]; Caitlin Loftus, An Apple a Day_If You Can Find One-Keeps the Doctor Away: How Food Deserts Hurt America's Health and How Effective Land Use Regulation Can Eliminate Them, 35 Zoning \& Plan. L. ReP. 1, 3 (2012). See also Policylink, The Grocery Gap: Who Has Access to Healthy Food AND Why it MATtERS: A REVIEW OF RESEARCH 6 (2013), http:/healthyfoodaccess.org/sites/default/files/ GROCERYGAP_FINAL_NOV2013_0.pdf. [https://perma.cc/7JGM-ERNH].

25. Loftus, supra note 24, at 2.

26. Emily M. Broad Leib, All (Food) Politics is Local: Increasing Food Access Through Local Government Action, 7 Harv. L. \& Pol'y Rev. 321, 325 (2013).

27. Nat'l Ctr. for Chronic Disease Prevention \& Health Promotion, State

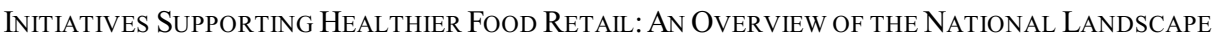
3-4 (2011), https://www.cdc.gov/obesity/downloads/healthier_food_retail.pdf [https://perma.cc/7T83-BPEP].

28. Sarah Corapi, Why It Takes More Than a Grocery Store to Eliminate a 'Food Desert', PBS Newshour (Feb. 3, 2014 4:43 PM), https://www.pbs.org/newshour/health/takes-grocerystore-eliminate-food-desert [https://perma.cc/93UJ-94M2]; Broad Leib, supra note 26, at 328.

29. Sheridan, supra note 6.

30. Definitions of Food Security, U.S. Dep't Agric., Econ. Res. Serv. (Sept. 5, 2018), https://www.ers.usda.gov/topics/food-nutrition-assistance/food-security-in-the-us/definitions-offood-security.aspx [https://perma.cc/L5GC-XP7F].

31. Id.

32. Food Insecurity in Indiana, supra note 2.

33. Id.

34. Jill Sheridan, Study Committee Discusses Food Deserts, Solutions, WFYI: INDIANAPOLIS (Sept. 6, 2017), https://www.wfyi.org/news/articles/study-committee-discusses-food-desertssolutions [https://perma.cc/5HAR-HLVN]. 

FOOD INSECURITY IN INDIANA

County, Allen County, and Lake County harboring Indianapolis, Fort Wayne, and Gary respectively.

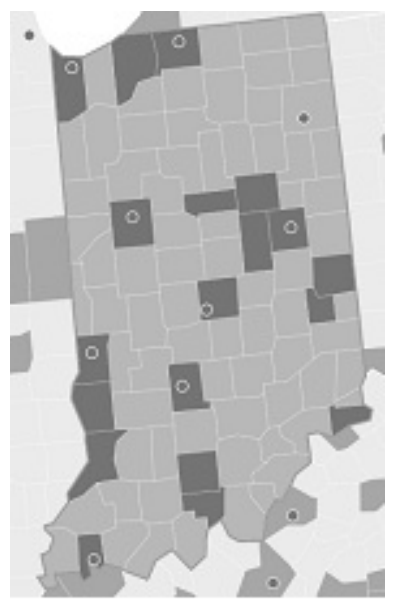
Food Insecurity Rates
$4 \cdot 148$
$15-19 \%$
20-24x
$25-29 \%$
$30 \%+$

Image and data from Map the Meal Gap based on data gathered in 2015. ${ }^{35}$

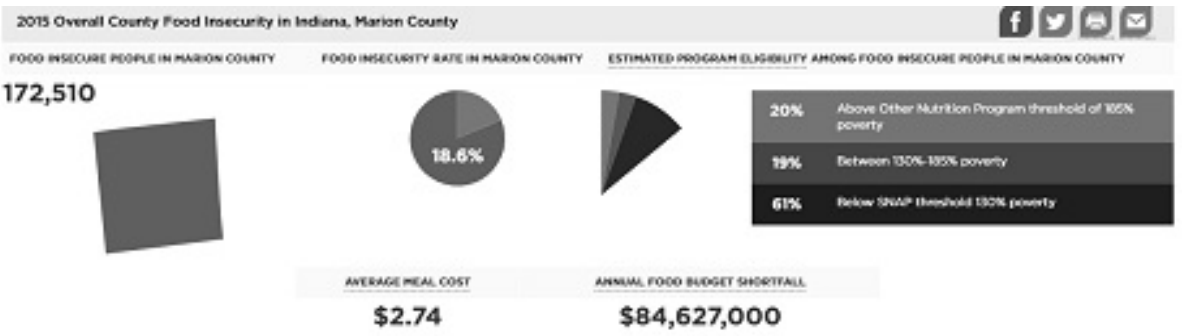

Food insecurity can branch into various facets of life and have negative externalities that impact not only families but communities as a whole. Studies have found that food insecurity can negatively impact a person's health, academic performance, and even the larger community ${ }^{36}$ Food insecurity in adults is linked to obesity, heart disease, and diabetes, while food insecurity in babies can cause low birth weights and frequent colds and stomach aches. ${ }^{37}$ These problems can

35. Food Insecurity in Indiana, supra note 2.

36. See infra notes $37-41$ and accompanying text.

37. Food Research \& Action Ctr., The Impact of Poverty, Food Insecurity, and Poor Nutrition on Health And Well-Being 4 (2017), http://frac.org/wpcontent/uploads/hunger-health-impact-poverty-food-insecurity-health-well-being.pdf [https://perma.cc/F4WS-VGM4]. 
become cyclic in nature because those who suffer from chronic food insecurity are more likely to ration medicine in order for the medicine to stretch longer, forgo foods needed for special medical diets, or postpone medical care. ${ }^{38}$ Studies have also shown that food insecurity leads to behavioral problems and mental distress in both children and adults. ${ }^{39}$ Data shows children are twice as likely to have behavioral problems if they have food-insecure mothers versus children with food-secure mothers. Additionally, food-insecure children between the ages of 14-25 are 2.3 times more likely to have depression or suicide ideation. ${ }^{40}$

Additionally, studies have found that children score better when supplied with healthy meals at lunch. ${ }^{41}$ A recent study completed on California elementary, middle, and high schools found that contracting with a healthy meal vendor increased students' performance on standardized testing between 3 and 4 percentile points. ${ }^{42}$ Finally, there have also been studies conducted on food insecurity and the impact it has on a community. Teenagers who face food insecurity will commit more minor crimes like shoplifting to put food on the table, and some teenagers will go as far as selling their bodies in exchange for a meal. ${ }^{43}$

Income is probably the most crucial factor that plays a role in food insecurity and food deserts, because this usually drives where a person can afford to live and what food they can afford to purchase. ${ }^{44}$ U.S. adults living with lower incomes have poorer health than higher incomes and the environment plays a large role in health. ${ }^{45}$ Safer, wealthier neighborhoods with parks and sidewalks make it easier for people to exercise outside. ${ }^{46}$ School districts with low per-student funding are

38. Id. at 5 .

39. Craig Gundersen \& James P. Ziliak, Food Insecurity And Health Outcomes, 34 Health AFF. 1830, 1833-35 (2015).

40. Id. at 1833-34.

41. Melinda D. Anderson, Do Healthy Lunches Improve Student Test Scores? ATLAnTIC (Mar. 22, 2017), https://www.theatlantic.com/education/archive/2017/03/do-healthy-lunchesimprove-student-test-scores/520272/ [https://perma.cc/74SR-JLKJ].

42. Id.

43. Susan J. Popkin et al., Urban Institute, Impossible Choices: Teens and Food INSECURITY IN AMERICA 16-20 (2016), https://www.urban.org/sites/default/files/publication/ 83971/impossible-choices-teens-and-food-insecurity-in-america_1.pdf [https://perma.cc/YZ52$72 \mathrm{NN}]$.

44. PolicyLinK, supra note 24, at 9-10 (an assessment in Missouri showed supermarkets in lower income neighborhoods had worse quality in produce than high income neighborhoods in the same city; African American women in low income neighborhoods of Chicago found multiple barriers to getting fresh produce including availability, quality and prices; white higher income, college- graduate neighborhoods in Baltimore, Maryland have better availability to healthy food options than black lower-income, less educated neighborhoods in Baltimore, Maryland).

45. Steven H. Woolf et al., Where Health Disparities Begin: The Role of Social and Economic Determinants-And Why Current Policies May Make Matters Worse, 30 HeAlth AfF. 1852,1853 (2011).

46. Id. at 1854 . 
more likely to have inexpensive, processed foods to feed children. ${ }^{47}$ Stress in the home and reduced "social cohesion," such as asking a neighbor for help, can also affect someone's health behavior. ${ }^{48}$

\section{B. State and Local Responses to Food Deserts and Food Insecurity}

Efforts to try to alleviate food deserts in Indiana have fallen short. In 2015, House Bill 1248 sought to establish programs to promote urban farming with an end-goal to bring fresh healthy foods to inner cities, but it failed to move past the Senate. ${ }^{49}$ In 2017 , Senate Bill 277 proposed loans and grants for new and existing businesses to offer fresh or unprocessed foods, but this bill failed to move past the Means and Ways Committee. ${ }^{50}$ In the same year, House Bill 1643 would have established a committee to study food deserts in Indiana; as could be predicted, this bill also fell short of passing. ${ }^{51}$ Again in 2017, yet another bill focusing on healthy food funding - House Bill 1077-failed to move past the Ways and Means committee, and it met the same fate of the prior bills aimed at tackling food insecurity. ${ }^{52}$ If passed into law, House Bill 1077 would have provided a "healthy food financing fund" to help finance loans and grants for affordable and healthy food options to "underserved communities." 53 Most recently in 2018, yet another bill similar to House Bill 1077-House Bill 1411—sought to establish a "new markets healthy food access investment credit" for investments made by the taxpayer into qualified low income community projects that are focused on bringing healthy, fresh food to low income areas. ${ }^{54}$ This bill too failed to make it past the Ways and Means Committee. ${ }^{55}$ Given the failed attempts by the legislature to bring relief to food-insecure communities, communities are taking steps on their own to help bring healthy foods to their neighborhoods. ${ }^{56}$

The Flanner House is a nonprofit on Indianapolis's northwest side that has focused on helping members of the community come out of poverty. The Flanner

47. $I d$

48. Id. at 1855 .

49. H.R. 1248, 119th Gen. Assemb. 1st. Reg. Sess. (Ind. 2015).

50. H.R. 277, 120th Gen. Assemb. 1st. Reg. Sess. (Ind. 2017); Sheridan, supra note 34.

51. H.R. 1643, 120th Gen. Assemb. 1st. Reg. Sess. (Ind. 2017).

52. H.R. 1077, 119th Gen. Assemb. 2d. Reg. Sess. (Ind. 2016); see also Adrianna Pitrelli, The Search for the Food Desert Solution, TheStAtehouseFile.com (Oct. 4, 2017), http://thestatehousefile.com/search-food-desert-solution/33309/ [https://perma.cc/KGR8-TARJ].

53. H.R. 1077, 119th Gen. Assemb. 2d. Reg. Sess. (Ind. 2016).

54. H.R. 1411, 120th Gen. Assemb. 2d. Reg. Sess. (Ind. 2018).

55. Id.

56. See Loftus, supra note 24 , at 4-5 (In the past decade the USDA has seen farmers markets triple from 2,863 to 6,000, and farmers markets are no longer only seen in higher-income neighborhoods but also lower income neighborhoods. Additionally, there has been a resurgence of communities coming together to bring community gardens, a trend that started during World War II and has since been revived.). 
House also happens to be in one of Indianapolis's largest food deserts. ${ }^{57}$ This year, the nonprofit partnered with Jonathan Lawler, a local Indiana farmer, to help farm one acre owned by Flanner House. The farm has brought the entire community together to help build a fence and pays local children to help with the farm work. ${ }^{58}$ Flanner House hopes to set up bodegas to sell the fresh food at affordable prices. ${ }^{59}$

Another non-profit in Fort Wayne - Growing Minds - also started an urban farm and provides educational courses in gardening and exposure to healthy food options. ${ }^{60}$ In the Emerson neighborhood in Gary, Indiana, a local church - Progressive Community Church — developed a small urban farm. ${ }^{61}$ That farm sells the produce, mainly kale, tomatoes, and green beans, on Wednesdays and Sundays. ${ }^{62}$ Additionally, the Emerson neighborhood also has ArtHouse: A Social Kitchen, which is a commercial kitchen to help local individuals interested in pursuing culinary work, and also acts as an incubator for culinary businesses in Gary. ${ }^{63}$ Yet another example is Good Food Connections, Inc., consisting of a conglomeration of multiple grass root organizations that found one another on Indianapolis's east side and discovered they would be more productive to pool their resources together. ${ }^{64}$ The organization provides food pantries on site to Section 8 apartment complexes and supports local community gardens. ${ }^{65}$

\section{TIF BASICS}

Tax increment financing is one of the most popular public financing tools for economic redevelopment. ${ }^{66}$ TIF adds to the revenue toolbox without having to necessarily rely on more traditional revenue sources such as increasing property

57. Cavan McGinsie, Flanner Farms Will Feed the Biggest Food Desert in Indianapolis, Nuvo (May 18, 2017), https://www.nuvo.net/food_and_drink/food_news/flanner-farms-will-feedthe-biggest-food-desert-in-indianapolis/article_020cdf70-3b37-11 e7-8d1b-c3966ff28bc2.html [https://perma.cc/ZB54-4B3B].

58. Id.

59. Id.

60. Lisa Ryan, Fort Wayne's First Urban Farm Brings Fresh Produce to Food Desert, WBOI: NORTHEAST IND. PUB. RADIO (Nov. 4, 2015), http://wboi.org/post/fort-waynes-first-urbanfarm-brings-fresh-produce-food-desert\#stream/0 [https://perma.cc/SF47-TAXE].

61. Giles Bruce, Healthy Food Projects Sprouting in Gary, Northwest Ind. Times (Oct. 2, 2016), http://www.nwitimes.com/lifestyles/healthy-food-projects-sprouting-ingary/article_329647a3-4194-5e27-8f33-ef28bde9ff08.html [https://perma.cc/B8GS-FRVT].

62. $I d$.

63. Id.

64. Denoon, supra note 9.

65. Id.

66. Bryon Eagon, TIF-for-Tax: Upholding TIF's Original Purpose and Maximizing Its Use as a Catalyst for Community Economic Development, 2017 WIS. L. REv. 179; Cory C. VanDyke, Note, Fields of Dreams: The Expectation and Common Reality of Tax Increment Financing, 79 UMKC L. REV. 791, 795-97 (2011). 
taxes or imposing special assessments. ${ }^{67}$

\section{A. History}

In the late 1940s, local governments created TIF as a means to self-finance redevelopment projects. ${ }^{68}$ California was the first state to implement TIF in 1952, and since then, forty-nine states and the District of Columbia have statutes regulating and permitting TIF ${ }^{69}$ A general increase for TIF occurred in the 1970s when the federal government reduced funds for redevelopment projects. ${ }^{70}$ In Indiana, during the years 2006, 2014, and 2015, the establishment of TIF districts surged. $^{71}$

\section{B. Function}

Originally, TIF was used as a tool to redevelop blighted urban areas, but it is now used as a financing technique for suburbs and rural areas as well. ${ }^{72}$ Municipalities use TIF for two different purposes: (1) to spur economic development in undeveloped areas known as Economic Development Areas or EDAs, or (2) to jumpstart underdeveloped areas known as Redevelopment Areas or RDAs. ${ }^{73}$ In either an EDA or an RDA, the funds from TIF are typically used to support, repair, or build new infrastructure in that particular TIF district. This includes supplying the funds to build or replace storm water drains, sewers, curbs, landscaping, sidewalks, roads, bridges, environmental remediation, or TIF revenue can be used to help finance a proposed development. ${ }^{74}$ Both the infrastructure and the debt financing methods are crucial lures that attract private developers to invest in that particular TIF district.

One important reason why TIF is a popular financing technique is because it gives local municipalities greater autonomy than other financing techniques.

67. Richard Briffault, The Most Popular Tool: Tax Increment Financing and the Political Economy of Local Government, 77 U. CHI. L. REV. 65, 68 (2010); VanDyke, supra note 66, at 79597.

68. Jeffrey Kleeger, Flexible Development Tools: Private Gain and Public Use, 46 URB. LAW. 377, 379 (2014).

69. Perry Burnett et al., Analysis of Tax Increment Financing in Indiana 3 (2016), http://www.ieda.org/resources/Documents/TIF-Final-\%20Report\%20June\%2023.pdf [https://perma.cc/5TZH-FEKW].

70. E.g., Briffault, supra note 67, at 69-70; VanDyke, supra note 66, at 792.

71. See Burnett ET AL., supra note 69 , at 21.

72. E.g., Phillip J.F. Geheb, Tax Increment Financing Bonds as "Debt" Under State Constitutional Debt Limitations, 41 URB. LAw. 725 (2009); Briffault, supra note 67, at 72.

73. E.g., BURNETT ET AL., supra note 69, at 35.

74. See J. Drew Klacik, Tax Increment Financing in Indiana, in TAX InCREMENT FinANCING and Economic Development 179, 185 (2001); Ind. Univ. Pub. Policy Inst., A Brief Look at TIF IN INDIANA 5 (2014), http://policyinstitute.iu.edu/uploads/publicationfiles/tif_report_2014.pdf [https://perma.cc/9VVS-M5RU]. 
Unlike other popular techniques - such as general obligation bonds-bonds borrowed against TIFs are not subject to any borrowing limit. ${ }^{75}$ TIF bonds issued by local municipalities to support redevelopment are not viewed as general obligation bonds and, therefore, do not need to adhere to state constitutional debt caps. ${ }^{76}$ This gives an opportunity for cities to fund redevelopment on an otherwise tight budget and also bypass the political games.

Generally, TIF is funded using three different techniques. ${ }^{77}$ First, redevelopment can be paid using tax revenue as it accrues. ${ }^{78}$ Second - and most popular - is through debt financing, and third is through a combination of both. ${ }^{79}$ The most common type of TIF financing in Indiana is through debt financing. ${ }^{80}$ Debt financing works by freezing the assessed base value of a blighted area before incorporating it into the redevelopment district, then re-assessing the value of the property once redevelopment is completed. ${ }^{81}$ The increment between the base assessed value and the future assessed value is then used as a security asset to secure bonds issued for that redevelopment. ${ }^{82}$ Any property taxes received which would have not been received based on the original base value during the time the TIF district is established for about thirty years, or until the TIF bonds mature, are then "captured" and redirected to a fund to pay back the TIF bonds. ${ }^{83}$ This is different from the typical fund incorporated into local budgets that pay for public services and facilities ${ }^{84}$ Indianapolis's downtown TIF, after decades of incurring increments, could amount to $\$ 59.3$ million by the end of $2018 .^{85}$

TIF debt financing, as mentioned above, is the most popular in Indiana. For example, let's suppose the fictional city, "North," decides to designate a three mile by three mile abandoned and blighted area as a TIF district called "North Redevelopment Area." The total amount of the assessed value of the redevelopment area prior to the designation of the TIF district is $\$ 500,000$. Once designated as a TIF district, with a redevelopment plan in place, the property value of North Redevelopment Area is re-assessed. The new assessed value for the North Redevelopment Area is $\$ 1,500,000$. North Redevelopment Commission can now pledge the $\$ 1,000,000$ tax increment proceeds as collateral for bonds that

75. Geheb, supra note 72 , at 726.

76. Id.

77. Ind. Univ. Pub. Policy Inst., supra note 74, at 5.

78. Id.

79. Id.

80. Id. (“[M]ajority of Indiana TIFs use debt financing (60 percent).”).

81. E.g., Briffault, supra note 67, at 67-68.

82. E.g., id.

83. Eagon, supra note 66 , at $184-85$.

84. E.g., Larry DeBoer, The Use of Tax Increment Finance by Indiana Local GOVERnMENTS 3-4 (2016), https://pcrd.purdue.edu/ruralindianastats/downloads/The-Use-of-TaxIncrement-Finance.pdf [https://perma.cc/T6GC-HF2X].

85. Kathleen McLaughlin, Downtown TIF District Awash in Cash, Indianapolis Bus. J. (Apr. 25, 2015), https://www.ibj.com/articles/52895-downtown-tif-district-awash-in-cash [https://perma.cc/8LZT-TEUU]. 
can be used to finance new infrastructure for the area. Any property tax revenue for the North Redevelopment Area that exceeds the base value of $\$ 500,000$ is now "captured" as TIF revenue and redirected to pay for the bonds. Once the bonds are mature and paid in full, which is typically between 25-30 years, the excess property tax revenue is no longer captured by a separate fund and is dispersed to the rest of the municipality.

\section{Indiana}

The Indiana General Assembly passed the Indiana Code establishing and regulating TIF in $1975 .{ }^{86}$ TIF districts spiked in Indiana in 2014 and 2015. ${ }^{87}$ TIF is used to spur economic growth in undeveloped or underdeveloped areas and has resulted in some debated success regarding property value gains and employment gains. ${ }^{88}$ According to the Indiana Gateway for Government Units site, in 2017, Indiana had 841 TIF Districts. ${ }^{89}$ Marion County alone had 34 TIF districts. ${ }^{90}$ TIF revenue can be used several different ways to promote economic development in underdeveloped or blighted areas - some places have done so, for instance, by repairing or providing new infrastructure to attract new businesses or financing some of the redevelopment projects such as stadiums or promenades to better serve the public. ${ }^{91}$ Finally, some of the funds can be used to entice developers by using bonds toward the redevelopment itself, such as for a parking lot. ${ }^{92}$

To take advantage of changes in federal law, between 1981 and 2015, Indiana made multiple changes to its code. Most of the changes were reflected in Indiana Code section 36-7-14 - the main statute for redevelopment commissions. ${ }^{93}$ The amendments to that section were made largely in response to citizen concerns regarding transparency issues, hoarding of excess funds, and siphoning money from other taxing units like schools and law enforcement. ${ }^{94}$

Since the 1980s, however, the articulated purpose of TIF in Indiana is to "benefit the public health, safety, morals and welfare" and increase the economic state of an undeveloped or underdeveloped area and serve to protect and increase property values. ${ }^{95}$ Additionally, TIF is meant to benefit the public by providing

86. See Klacik, supra note 74 , at 179.

87. BuRnetT ET AL., supra note 69, at 19.

88. E.g., id. at 1-7.

89. Statewide TIF District Summary for Calendar Year 2017, supra note 10.

90. Id.

91. See George Lefcoe, Competing for the Next Hundred Million Americans: The Uses and Abuses of Tax Increment Financing, 43 URB. LAw. 427 (2011); Eagon, supra note 66, at 179; Klcsik, supra note 74, at 179, 185.

92. See Eagon, supra note 66, at 179; Klacik, supra note 74, at 179, 185; Lefcoe, supra note 91.

93. Ind. Univ. Pub. Policy Inst., supra note 74, at 1.

94. See generally BuRnetT ET AL., supra note 69, at 26-31.

95. IND. CODE $§ 36-7-14-2.5$ (2017). 
public funds at low interest rates to private developers because such a public betterment could not be accomplished through regular "public or governmental functions." ${ }^{\prime 6}$ The local commissions achieve this purpose by determining what areas need redevelopment through various forms of due diligence. Due diligence in the redevelopment area context includes surveys, studies, and investigations to determine the cause of the redevelopment and the actions needed, as well as working with different government units to "promote the use of land in a manner that best serves the interests of the unit and its inhabitants."97

The municipal and executive legislature appoints the local commission to oversee the redevelopment area. ${ }^{98}$ The local commission consists of five board members - seven if it is a county redevelopment commission - with one of the board members serving as a nonvoting advisor. ${ }^{99}$ The nonvoting advisor "must also be a member of the school board of a school corporation that includes all or part of the territory served by the redevelopment commission." 100

In Indiana, a redevelopment commission can use TIF for Redevelopment Areas or for Economic Development Areas." ${ }^{101}$ Although Redevelopment Areas and Economic Development Areas seem similar, they have different statutory requirements which the redevelopment commission must find when allocating an area for TIF. Originally, the Indiana Code used the terms "blighted" or "deteriorated" to determine areas needing to be redeveloped, but on June 30, $2005,{ }^{102}$ the Indiana Code redefined an "[a]rea needing redevelopment" as:

[A]n area in which normal development and occupancy are undesirable or impossible because of any of the following:

(1) Lack of development.

(2) Cessation of growth.

(3) Deteriorated or deteriorating improvements.

(5) Character of occupancy.

(6) Age.

(7) Obsolescence.

(8) Substandard buildings.

(9) Other factors that impair values or prevent a normal use or development of property. ${ }^{103}$

The conditions listed above from Indiana Code section 36-7-1-3 cannot be cured through "regulatory processes" or "ordinary operations of private enterprise" and will benefit "public health and welfare." 104 This is somewhat distinct from an

96. $I d$.

97. Id. $\S 36-7-14-11$.

98. Id. § 36-7-14-1; § 36-7-14-3.

99. Id. $\S 36-7-14-6.1$.

100. Id. $\S 36-7-14-6.1(\mathrm{~d})$.

101. Id. § 36-7-14-1.

102. Id. § 36-7-14-1.3.

103. IND. CODE $§ 36-7-1-3$ (2005).

104. IND. CODE $\S 36-7-15.1-8$ (2017). 
Economic Development Area which is an area that the redevelopment commission finds that:

(1) the plan for the economic development area:

(A) promotes significant opportunities for gainful employment of its citizens;

(B) attracts a major new business enterprise to the unit;

(C) retains or expands a significant business enterprise existing in the boundaries of the unit; or

(D) meets the other purposes of sections 2.5 and 42 of this chapter[.] ${ }^{105}$

Like the Redevelopment Area, the Economic Development Area must benefit public health and safety, and increase economic well-being which cannot be accomplished through "ordinary operations of private enterprise." ${ }^{\prime 106}$ An EDA is more liberally applied than an RDA and is geared towards bringing economic development to an underdeveloped area. In contrast, the Redevelopment Areas are used to spur economic growth from areas that have seen stagnation for numerous reasons.

To create a TIF district, the redevelopment commission must first gather data on an area that it believes is a "menace to social and economic interest of the unit and its inhabitants," and will be beneficial to the public to acquire, re-plan, and redevelop the area. ${ }^{107}$ After gathering data, the commission then determines the boundaries of the area, which parcels will be affected by the redevelopment, and outlines the future public purpose of the area. ${ }^{108}$ Finally, the commission needs to determine the final cost of the project-including both acquisition and redevelopment - and submit their proposal to the appropriate local legislative body for approval. ${ }^{109}$

\section{Debate Surrounding TIF in Indiana}

Despite the ostensibly public purpose behind TIF, the TIF system faces many critics. For instance, Ball State University released a study in 2016 that reported $\$ 320$ million in property tax revenue was diverted from government agencies, like schools, because of TIF. ${ }^{110}$ This argument is based on a popular critique that property taxes would have increased naturally; therefore, any increasing revenue above the base value that was being redirected to pay back the TIF could have

105. Id. § 36-7-14-41.

106. Id. § 36-7-14-2.5.

107. Id. $\S 36-7-14-15$.

108. Id. $\S 36-7-14-11$.

109. Id. § 36-7-1-3.

110. Michael J. Hicks et al., Ball State Univ. Ctr. for Bus. \& Econ. Research, The FisCAL IMPACT OF TAX INCREMENT FINANCING IN INDIANA 1 (2016), https://projects.cberdata.org/ reports/FiscalTIF-20160129.pdf [https://perma.cc/UN86-7H5C]. 
been shared among other government units instead. ${ }^{111}$ The report suggests correcting this diversion of revenue by making the base assessed value subject to inflation during the term of the TIF. ${ }^{112}$ Additionally, a report by the Indiana Economic Development Association found that the difference in employment between TIF allocated areas and non-TIF areas is only .7\%, which would insinuate TIF does not bring as many jobs as projected. ${ }^{113}$ Other common arguments are that TIF shifts retail sales instead of creating new sales tax revenue to the area, and that TIF creates competition with neighboring counties creating an overall negative impact. ${ }^{114}$ Finally, critics argue TIF can be used too liberally as "corporate giveaways" to large corporations who would not need the tax incentive to create facilities in that area, such as large retailers like Wal-Mart and Cabela's. ${ }^{115}$

\section{HOW INDIANA SHOULD USE TIF TO ALLEVIATE FoOD DESERTS AND FOOD INSECURITY}

The prevalence of TIF districts and food deserts in Indiana provides a valuable opportunity for TIF redevelopment commissions to play a role in eradicating food deserts and addressing food insecurity. The use of TIF as a vehicle to bring grocery stores to food deserts is a functional and realistic way to alleviate food insecurity in Indiana. Alternatively, it gives an opportunity for redevelopment commissions to work directly with the community to address other neighborhood needs like safe public spaces, community gardens, and farmers markets.

\section{A. Additional Provisions in the Indiana Code}

The duties of a redevelopment commission are specifically outlined in Indiana Code section 36-7-14-11 and allow the legislature to create multiple different redevelopment commissions. Some of the commission's duties include investigating areas needing redevelopment, pinpointing the causes requiring the redevelopment, and determining the best way to address these causes. ${ }^{116}$ Further, local redevelopment commissions have the power to acquire lands, to remediate the lands of hazardous materials if needed, to determine the use of the lands, to work with any agency or department, to sell land to developers, and to remodel or rebuild structural improvements on the land, along with a plethora of other duties all in accordance with the purpose of the Act. ${ }^{117}$

The purpose and the duties of the redevelopment commission are interpreted broadly. In an attempt to keep the powers of the redevelopment commission in

111. Id. at 9 .

112. BuRnetT ET AL., supra note 69 , at 9.

113. Id. at 8 .

114. See BurnetT ET AL., supra note 69, at 9; HicKS ET AL., supra note 110, at 9.

115. See Lefcoe, supra note 91, at 443-44.

116. IND. CODE $§ 36-7-14-11$ (2017).

117. Id. $\S 36-7-14-12.2$. 

FOOD INSECURITY IN INDIANA

check, the Indiana legislature passed Senate Enrolled Act 118 ("SEA 118"). ${ }^{118}$ SEA 118 requires redevelopment commissions to provide "a specific finding of fact, supported by evidence, that the adoption of the allocation provision will result in new property taxes in the area that would not have been generated but for the adoption of the allocation provision" (emphasis added). ${ }^{119}$ SEA 118 also enacted more oversight over the redevelopment commission in terms of creation or expansion of TIF districts, review of annual budgets, approval for bonds in excess of $\$ 5,000,000$ and removal of the redevelopment commission's eminent domain power. ${ }^{120}$ All of these procedures stripped some of redevelopment commissions' the local autonomy and inadvertently created a roadblock to bringing a grocery store to Avondale Meadows, a low-income neighborhood in Indianapolis. ${ }^{121}$

Avondale Meadows, previously known as a low-income, high-crime neighborhood in Indianapolis's northeast side, was lacking a grocery store. ${ }^{122}$ In 2012, Republican Councilwoman Christine Scales, from District 3 in Indianapolis, proposed expanding an existing TIF district to include Avondale Meadows. ${ }^{123}$ Avondale Meadows had already successfully attracted a charter school, a new East Village apartment complex, and a YMCA; but the area still lacked a grocery store and anchor tenant. ${ }^{124}$ In 2013 Councilwoman Scales sought to approve the expanded TIF district again, but it was tabled to make sure all other options were exhausted. ${ }^{125}$ Councilwoman Scales continued work on this for over two years trying to gain the votes she needed from the Metropolitan

118. S. 118, 118th Gen. Assemb. 2d. Reg. Sess. (Ind. 2017).

119. IND. CODE § 36-7-14-39.

120. S. 118, 118th Gen. Assemb., 2d Sess. (Ind. 2014).

121. Brian Eason, Six Months to Fix a Map? Delays Rile Indy Council, Indianapolis StaR (Feb. 12, 2015, 9:00 AM), https://www.indystar.com/story/behind-closed-doors/2015/02/12/a-tiftiff-indy-councilman-ticked-by-delays/23194647/ [https://perma.cc/4TGZ-KGNW].

122. See, e.g., Zach Myers, \$55 Million Coming to Indy for Community Projects, Fox 59, $\mathrm{http}$ ://fox 59.com/2017/01/24/55-million-coming-to-indy-for-community-projects/ [https://perma.cc/KR9T-6QZL] (noting that Avondale Meadows is a historically high-crime area); Erika Sanders, New Beginning for Meadows: \$150M in Community Renovations Under Way, INDIANAPOLIS RECORDER NEWSPAPER (Sept. 30, 2011) http://www.indianapolisrecorder.com/ news/local/article_5f65cb6c-eb3f-11e0-8268-001cc4c03286.html [https://perma.cc/PT2E-9DJK] (interviewing Gant, a resident, who said "[Avondale Meadows] isn't safe for anyone"); Metropolitan Economic \& Development Committee, Meeting Minutes, Jan. 14, 2013 (Speaking at the meeting, Dr. Cynthia Stone stated that the Avondale Meadows area has a high number of low-income families.) (on file with author).

123. Meeting Minutes, Jan. 14, 2013, supra note 122 (noting that Councilwoman Scales expressed frustration because the proposal was tabled and stated she had proposed the Avondale Meadows TIF in 2012).

124. Id. (noting that Councilwoman Scales stated [Avondale Meadows] had just welcomed a YMCA but that the area still needed a grocery store).

125. Id. (noting the proposal for the Avondale Meadows TIF was tabled). 
Economic Development Committee ("MEDC") to pass the TIF expansion. ${ }^{126}$ At the meetings to debate the new TIF district, dozens of local community leaders came to speak in support of the TIF expansion, and Councilwoman Scales stated she already had a grocery store lined up, but needed tax incentives to bring the deal full circle. ${ }^{127}$ In 2014, Scales partnered with Councilwoman Pam Hickman, and together they worked to re-propose the Avondale Meadows TIF and included plans to use the funds for workforce training and micro-loans for small businesses in addition to the grocery store. ${ }^{128}$ Councilwoman Scales eventually passed the entire project onto Councilwoman Hickman after multiple meetings and debates. ${ }^{129}$ Finally the TIF deal passed in August of 2015. ${ }^{130}$ Unfortunately, by the time it passed, new changes to TIF required legislative approval to expand a TIF district and for the area to conform to the new definition of what constituted a Redevelopment Area. As a result, progress toward bringing a much needed grocery store to a food desert came to a halt, and the TIF map had to be redrawn and reapproved, by the legislative body. store. ${ }^{131}$ Finally, the neighborhood, which had not had a grocery store in 20 years, finally opened a Save-A-Lot in February of 2017 using a Housing of Urban Development Loan instead of utilizing TIF funds. ${ }^{132}$

There are many potential solutions to the problems presented above. One solution would be to amend the Code so that approval for TIF expansion did not require approval from the legislative body, which, in this case, would have fasttracked the Avondale Meadows TIF rather than create a political gridlock. But this would undermine SEA 118, which specifically added more steps for redevelopment commissions to stop them from going rogue and expanding

126. See generally id. (noting the proposal for the Avondale Meadows TIF was tabled); Metropolitan Economic \& Development Committee, Meeting Minutes, Jan 13, 2014, (noting the proposal for Avondale Meadows was TIF postponed until March 2014) (on file with author); Eason, supra note 121 (noting the boundaries of the Avondale Meadows TIF need to be revised); Metropolitan Economic \& Development Committee, Meeting Minutes, Mar. 16, 2015 (noting motion passed to correct the boundaries of the Avondale Meadows TIF) (on file with author).

127. Meeting Minutes, Jan. 14, 2013, supra note 122 (noting Councilor Scales stated "[t]hey now have a quality grocery store waiting in the wings, willing to invest in this area, but will not proceed without some kind of tax incentive; in the form that can be offered through TIF").

128. Metropolitan Economic \& Development Committee, Meeting Minutes, July 21, 2014 (on file with author).

129. Kathleen McLaughlin, Christine Scales, a Councilor with an Independent Streak, Riles Both Parties, Indianapolis Bus. J. (June 14, 2014), https://www.ibj.com/articles/48106?v= preview?v=preview [https://perma.cc/2B3F-SZ24].

130. Eason, supra note 121.

131. Id.

132. Matt McKinney \& Eric Cox, Grocery Store Opening in Indianapolis Food Desert, RTV6 (Feb. 1, 2017, 9:25 AM), https://www.theindychannel.com/news/local-news/grocery-store-openingin-indianapolis-food-desert [https://perma.cc/K5KM-UPSL]; Metropolitan Economic and Development Committee, Meeting Minutes, Aug. 31, 2015 (on file with author). 

FOOD INSECURITY IN INDIANA

endless TIF districts. ${ }^{133}$ Another solution would be to revert the definition of a "Redevelopment Area" to its original definition. This would have been an easier criterion to meet for Avondale Meadows. Yet again, this solution, like amending the Code to allow faster expansion, would have undermined the carefully planned processes that were instituted in SEA 118, and although these solutions are completely plausible, they might not be successful especially given TIFs recent criticisms. ${ }^{134}$

Given the hesitation and potential public upheaval that may come from making changes established by SEA 118, there is yet a third solution which could fast-track TIF expansions and new TIF districts. The solution is two-fold and would hinge on the need to eradicate a food desert or fight food insecurity. The first part of the solution would require amending the definition of a "Redevelopment Area" to include areas that are in a food desert as defined by the USDA. ${ }^{135}$ This would help areas like Avondale Meadows that do not meet any criteria for a Redevelopment Area but, nonetheless, desperately need the development of a grocery store that otherwise would not be established without an economic incentive.

The second part of the solution would make it easier to both establish a new TIF district and to expand a current TIF district by revising the Indiana Code to include a food and health impact study prior to any creation or expansion. Even if the TIF district is not located in a food desert, food insecurity might still exist. ${ }^{136}$ For instance, some families in Hamilton County — one of the wealthiest counties in Indiana - still suffer from food insecurity. ${ }^{137}$ Therefore, analysis of an expansion or creation of a current TIF district should include an impact study that directly addresses how the redevelopment will impact the health of the residents in the area. For instance, will it bring affordable food options? Will the food options be accessible to the population by bus or along a bike trail? Will there be an opportunity in the proposed redevelopment to create more than one health and wellness center, such as a community garden or civic center that will host after school meals or nutrition classes? This two-part solution should specifically be used for TIF districts as TIF districts have more local autonomy, and more importantly, usually address multi-faceted problems that cause food insecurity such as employment, education, and culture.

TIF should be used to eliminate food deserts because (1) the vehicle to create this change already exists, and (2) the main function of TIF is to benefit the public. No new vehicle or structure needs to be established. An existing commission's structure is devoted to working with public and private entities to succeed in bringing redevelopment to a TIF district, something scattered community groups would have difficulty organizing. Additionally, the Indiana

133. See S.B. 118, 118th Gen. Assemb. 2d. Reg. Sess. (Ind. 2017).

134. See, e.g., HICKS ET AL., supra 110, at 9.

135. IND. CODE $§ 36-7-1-3$ (2017).

136. Carter, supra note 3.

137. Id. 
Code has specific statutes that are designated to give "community development corporations" land and title to them at no cost. ${ }^{138}$ This is an outright win for nonprofits like Growing Minds, Flanner House, and community organizations like Good Foods, Inc.

Another compelling use of TIF as a vehicle to rid food deserts is the local autonomy associated with TIF. Redevelopment commissions that establish TIFs are decentralized government commissions focused on a particular area that has the means to revitalize an entire area to best serve that community. ${ }^{139}$ A TIF created by a redevelopment commission has very little "red tape," and it has minimal federal regulation. ${ }^{140}$ Additionally, it is not subject to state debt caps or regulations for general obligation bonds. ${ }^{141}$ TIF can happen without raising property tax rates, which can be a political nightmare, and only generates revenue when property taxes exceed the base value.

\section{Multi-Faceted Solution}

The reason why redesigning part of the Indiana Code to include research on food insecurity in a particular proposed TIF district and to automatically make food deserts a qualifier for RDAs is because TIF is a multi-faceted solution. Food deserts and food insecurity are a result of two overarching and independent problems: access and affordability. Being cognizant of how new development may affect the neighborhood has both direct and indirect effects on food insecurity and health. Direct effects are the obvious ones: access to affordable and healthy grocery stores, farmers markets, bodegas, and more community gardens. Indirect effects would look more like infrastructure, accessible public transportation, sidewalks and parks, safer neighborhoods, affordable housing, and employment. After all, the main purpose to use TIF is to redevelop an entire area to spur economic activity. This would mean an increasing number of employment opportunities, various income levels living in one area, and public spaces. A successful food desert TIF would help break the cyclical socioeconomic problems that occur in low-income neighborhoods. Using the example of Jane Smith in the Introduction of this Note, I will work through how TIF can answer her food insecurity problems in more ways than one.

1. Direct Effect.-Access is one of the easiest problems to address. Research has shown that living near a grocery store or supermarket is correlated with more nutritional eating habits. ${ }^{142}$ Given that grocery stores already have relatively low profit margins, owners are hesitant to move grocery stores into low-income areas. ${ }^{143}$ It seems very unlikely that every food desert located in or near a TIF district will have the chance to incorporate a grocery store, especially a smaller,

138. IND. CODE $\S 36-7-14-22.2$.

139. Briffault, supra note 67 , at $84-85$.

140. Id. at 83 .

141. Geheb, supra note 72 , at 726.

142. PolicyLinK, supra note 24 , at 7.

143. Loftus, supra note 24 , at $4,7$. 

FOOD INSECURITY IN INDIANA

locally owned grocery store. This, however, is just another reason why TIF in Indiana is a multi-faceted solution. TIF funds do not have to rely solely on attracting businesses, and in fact the most successful TIFs do not have that main purpose. ${ }^{144}$ Rather, the TIF focus is to revitalize an area and part of that revitalization is community development which can be born from community gardens, designated parks that serve dual purposes such as a farmers market, or a public building that hosts a pantry, soup kitchen, or gives nutrition lessons. TIF can be used to fund all of these scenarios because it serves a public purpose. Furthermore, TIF can provide other solutions that would help secure food for its neighborhood residents. For instance, studies have found that people with food insecurity have such insecurity because their income is being used towards other life-sustaining needs such as rent or mortgages, car payments, or child care. ${ }^{145}$ The most pressing problem regarding food deserts and food insecurity is the affordability factor. Therefore, what will be just as important as establishing an area for urban farming or building a public facility to host cooking and nutrition classes, are the indirect effects that the TIF district can bring to a community.

2. Indirect Effect.- Though TIF's main purpose is not to attract businesses, the outcome of pouring funds into infrastructure in the neighborhood allows for just that. For instance, in Fort Wayne, a vacant potato chip factory would not have drawn any investors to the abandoned area, due to flooding from stormwater runoff. ${ }^{146}$ TIF funds were used to eradicate the flooding, and now the site hosts Costco and a Longhorn restaurant. ${ }^{147}$ These businesses, in-turn, bring jobs to residents in the surrounding area, and these businesses help retain jobs for businesses in areas that are suffering. ${ }^{148}$ But even if Jane Smith, from this Note's Introduction, lived near this Fort Wayne TIF district, business redevelopment would do little for her lack of access and transportation to a grocery store. Yet again, this example demonstrates how TIF is multi-faceted.

As mentioned in Section II of this Note, TIF is used to fund infrastructure, including sidewalks, bike trails, and widening roads for buses. ${ }^{149}$ This could make transportation within metropolitan areas easier and would greatly benefit low income individuals who struggle with reliable transportation. This could also

144. Thomas P. Healy, Midtown TIF: Designed for Success, Indy Midtown Mag. (Feb. 8, 2016), https://www.indymidtownmagazine.com/midtown-tif-designed-for-success/ [https://perma.cc/EGG8-ER5U] (stating that the Midtown TIF was not built to attract businesses but to develop the area with the entire goal being "diversity, equity, and urban redevelopment").

145. E.g., FEEDING AMERICA, supra note 12, at 3.

146. Dave Gong, Fort Wayne, Allen County Officials Say 20 TIFs Boost Local Economy, IND. ECON. Dig. (Feb. 15, 2015, 3:40 PM), http://indianaeconomicdigest.com/main.asp?SectionID= 31\&subsectionID=299\&articleID=78396 [https://perma.cc/WEJ9-8VLG].

147. Id.

148. Jonathan Streetman \& Candy Neal, Huntingburg and Jasper Mayors Disagree with BSU Study's Criticism of TIF, IND. ECON. DiG. (Feb. 12, 2015, 5:35 PM), http://indianaeconomicdigest. com/main.asp?SectionID=31\&subsectionID=299\&articleID=783 [https://perma.cc/PYB6-RT39].

149. See discussion supra Section II.B. 
have an indirect effect on food insecurity, as transportation is cited as a reason many residents do not have access to healthy and affordable foods. ${ }^{150}$ The ability to safely walk or ride bikes in an area has a positive impact on health and stress of an individual. ${ }^{151}$ Although this is not directly related to food security, it too benefits the overall health of a community.

Some other problems Jane Smith faces are her ability to pay for rent, care for her parent, and work full time. For residents on tight budgets, affordable housing might give them an opportunity to reduce some of their budget costs and then reallocate those savings towards food and health care expenses. Affordable housing is another common usage of TIF funds. ${ }^{152}$ In addition to giving neighborhoods a chance to diversify with different income levels, affordable housing also slows the effects of gentrification in a new area. ${ }^{153}$ These housing establishments usually are considered low to moderate income and are mixed with market-rate apartments as well. ${ }^{154}$ Again, this can help the general cohesion of the neighborhood as a whole. Although this is not related directly to food insecurity, it is a positive externality that could have positive effects on the neighborhood as a whole. For instance, some grocery stores avoid low-income areas because grocery stores, as mentioned above, already have low-profit margins ${ }^{155}$ larger stores are attracted to higher income areas. ${ }^{156}$ Therefore, if a TIF district has a mixture of both low and high-income residents, the low-income residents will likely benefit from the presence of higher income families and individuals.

The micro-level participation of the proposed redevelopment commissions provides yet another positive indirect effect of the proposed food desert TIF. The redevelopment commissions are subject to public oversight, and successful TIF districts have many forums for public input because, besides attracting businesses, urban TIF districts are seeking community revitalization as well. ${ }^{157}$

150. See PolicyLink, supra note 24 , at $11,13,15$.

151. See Paula Braveman \& Laura Gottlieb, The Social Determinants of Health: It's Time to Consider the Causes of the Causes, 129 Pub. Health Rep. 19, 19 (Supp. II 2014).

152. See Indianapolis-Marion Cty. Council Tax Increment Fin. Study Commission, FinAL REPORT 13 (2012), http://www.indy.gov/eGov/Council/Committees/Documents/TIF\% 20 Study\%20Commission_Final\%20Report\%20_\%20June\%2029,\%202012.pdf [https://perma.cc/2HTK-ZYGP].

153. Diane K. Levy et Al., Keeping the Neighborhood Affordable: A Handbook of Housing STRATEgIES FOR GENTRIFYING AREAS 3, 10-11 (2006), https://www.urban.org/sites/ default/files/publication/50796/411295-Keeping-the-Neighborhood-Affordable.PDF [https://perma.cc/ZQZ5-44UT].

154. Mixed-Income Housing, BANKRATE, https://www.bankrate.com/glossary/m/mixedincome-housing/ [https://perma.cc/5UYV-5H8M] (last visited July 7, 2019).

155. Loftus, supra note 24, at 6.

156. See, e.g., id. at 9.

157. Healy, supra note 144 (stating that the Midtown TIF was not built to attract businesses but to develop the area with the entire goal being "diversity, equity, and urban redevelopment," and that in the process of creating the TIF public review was probably "the largest public dialogue that 

FOOD INSECURITY IN INDIANA

In the Avondale/Meadows TIF district, the advocates - Councilwomen Scales and Hickman - frequently solicited public opinions, and subsequently included a workforce training program and a small business loan program in their redevelopment plan to help local businesses commit to the Avondale/Meadows area. ${ }^{158}$ Similarly, the North Midtown TIF district in Indianapolis also took into consideration community input in its redevelopment design, and it therefore included a grocery store and low to moderate income housing in its design. ${ }^{159}$ Because redevelopment commissions are more directly involved in the community and have the sole focus of just one TIF area, there is a better opportunity for people like Jane Smith, to have their concerns heard. Again, these results from using TIF are not the direct effects we expect on food insecurity, but rather additional indirect effects that could help those on tight incomes with only having the ability to work part time.

Finally, the last positive indirect effect of a proposed food desert TIF district would be the potential employment TIF brings by attracting new businesses or supplying new infrastructure projects to local developers or construction companies. Traditionally, TIF can help lower unemployment in the area by attracting new businesses or helping existing businesses expand. ${ }^{160}$ An example of this is the Fort Wayne scenario above. ${ }^{161}$ The most ideal scenario would be if a TIF district in or near a food desert were to attract a grocery store or supermarket because that supermarket would bring to the community direct access to healthier foods as well as new jobs. The Avondale Meadows grocery store that was eventually put in place had 36 full-time and part-time jobs, and 35 out of 36 of those jobs were filled by Avondale Meadows residents. ${ }^{162}$

has occurred on TIF in Marion County in 40 years."(statement of Michael McKillip)); See, e.g., Meeting Minutes, Jan. 14, 2013, supra note 122, at 6-11 (detailing the dialogues between various citizens and community representatives from the Avondale/Meadows neighborhood).

158. Meeting Minutes, July 21, 2014, supra note 128, at 2-5 (detailing the workforce training program, the small business micro-loans, and the continued need for a grocery stores, "Councillor Hickman stated that they are asking for a grocery store in the area that is walkable and affordable. She said they are being responsible in what they put into the neighborhood because what they [sic] neighbors need is what they want to put there, not something someone else wants." Id. at 4).

159. See Mixed-Use Development Provides Dramatic Gateway to Broad Ripple, MiDTown INDY, https://midtownindy.org/project/the-coil-building/ [https://perma.cc/H5YK-BVJ8] (last visited July 7, 2019) (discussing The Coil, a mixed-use development which included a grocery store, that used \$5.7 million in TIF funds for sidewalks, landscape improvements, utility relocation, public plaza, etc.).

160. See, e.g., Fiscal Analysis Dep't, Minn. House of Representatives, Job Creation and TIF, 13 Money Matters 1, 5-6 (June 17, 1998), https://www.house.leg.state.mn.us/fiscal/files/ 98tifjob.pdf [https://perma.cc/8EHM-A9VT].

161. See discussion supra Section III.C.3.

162. Julian Grace, Save-A-Lot Gives Hope to Avondale Meadows, WISHTV (Feb. 1, 2017, 7:57 PM), http://wishtv.com/2017/02/01/save-a-lot-gives-hope-to-avondale-meadows/ [https://perma.cc/V4V3-7LJK]. 
The micro-level oversight with public input is a large part of why TIF districts are the answer to food insecurity and food deserts in Indiana. In Gary, Indiana, TIF funds were used to update infrastructure, demolish abandoned buildings and support a new community-center-the non-profit ArtHouse. ${ }^{163}$ The ArtHouse not only acts as a platform for cooking and nutrition classes for the community, but it also offers training for residents in commercial culinary fields, and even acts as an incubator for local small restaurants and catering companies. ${ }^{164}$ This is yet another example of how TIF can be a multi-faceted tool to address food insecurity in Indiana's metropolitan areas.

Critics point out the correlation of higher tax rates in TIF districts and the weak effects TIF has on raising employment and income levels. The most prominent criticism, cited by many journalists throughout Indiana, ${ }^{165}$ is the Ball State University study mentioned above in Part II of this Note. ${ }^{166}$ The study found TIF had no significant increase in employment or income levels and instead correlated with an increase in tax rates. ${ }^{167}$ Although this criticism is not without merit, a few things should be made apparent.

First, the study only focused on TIF districts created from 2003-2012. ${ }^{168}$ A major national event occurred in the midst of this study-the Great Recession-which caused an increase in unemployment across the United States. ${ }^{169}$ Second, because the study stopped after 2012, it does not include many successful TIF districts - such as the North Midtown TIF, which has seen positive economic redevelopment in the particular TIF district. ${ }^{170}$ Additionally, even the

163. What is a TIF?, CITY GARY REDEVELOPMENT COMMISSION, http://www.garyredev.org/ tif-districts.html [https://perma.cc/9EGA-P2KN] (last visited July 7, 2019).

164. About, ArtHouse: A Social Kitchen, http://arthousegary.com/ [https://perma.cc/GA9Y-XP9B] (last visited July 7, 2019).

165. See, e.g., Kevin Allen, Is There Too Much TIF in St. Joseph County?, South Bend TRIB. (Feb. 10, 2016), https://www.southbendtribune.com/news/business/is-there-too-much-tif-in-stjoseph-county/article_79030d91-91c0-5c1f-95d6-af37541383c1.html [https://perma.cc/A8BREKPR]; Ryan Delaney, Reports Says TIF Districts are Net Loss for Local Governments, WFYI INDIANAPOLIS (Feb. 9, 2016), https://www.wfyi.org/news/articles/reports-says-tif-districts-are-netloss-for-local-governments [https://perma.cc/T6GX-QX88]; Christin Nance Lazerus, Gary Schools Looking for Ways Out of Huge Deficit, CHI. TRIB. (Sept. 6, 2016, 2:23 PM), http://www.chicagotribune.com/suburbs/post-tribune/news/ct-ptb-gary-finances-options-st-090320160906-story.html [https://perma.cc/K4WK-6PNH].

166. HICKS ET AL., supra note 110, at 9.

167. Id.

168. Id. at 4.

169. U.S. Bureau of Labor Statistics, BLS Spotlight on Statistics: The Recession of 2007-2009, at 2 (2012), https://www.bls.gov/spotlight/2012/recession/pdf/recession_bls_spotlight. pdf [https://perma.cc/T93Z-9294].

170. See Healy, supra note 144 (citing Hicks, the co-author of the Ball State Study, "The Midtown TIF is more like what TIFs were designed to do when they first sprang in to the public policy sphere in the 1970s — urban redevelopment."); see also Gong, supra note 146 (citing Hicks, the co-author of the Ball State Study, "If I were to pick four places statewide where I could say 
co-author of the study, Hicks, has pointed out that there are many productive uses of TIF when the municipalities using them are fiscally conservative, and he points to even the relatively fiscally liberal Indianapolis and Fort Wayne as being examples of productive TIF use. ${ }^{171}$ Finally, mayors of non-metropolitan areas disagree with the Ball State study. ${ }^{172}$ The mayors of Hicksburg, Indiana, and Jasper, Indiana, have claimed that the use of TIF funds may not have brought new businesses, but has helped current businesses expand and add more jobs. ${ }^{173}$

\section{CONCLUSION}

Tax increment financing can be used as a tool to address food insecurity and food deserts in Indiana. Revising the Indiana Code to make it easier to create or expand TIF districts in Indiana when there is a need for healthy and affordable food options in that TIF area can make a very real change for many low-income, low-access areas. Additionally, the change in the Indiana Code would help bring immediacy to a dire problem, rather than waiting years as in the case of the above-mentioned Avondale Meadows. Finally, the impact of TIF expands beyond just addressing access and affordability to healthy foods, but also addresses many of the other socioeconomic issues that surround food insecurity, such as unemployment, lack of public transportation, and lack of community cohesion. ${ }^{174}$ By confronting food insecurity head-on with this change in the Indiana Code, Indiana can reverse its devastating upward trend in food insecurity and use government funds for their quintessential purpose, to serve the public.

there have been good use of TIFs, I would say Indianapolis, Fort Wayne, the Toyota plant in Princeton and the Honda plant in Greensburg.").

171. Gong, supra note 146.

172. See Streetman \& Neal, supra note 148.

173. Id.

174. See discussion supra Section III.C.2. 